\title{
First Episode of Shell Disease Syndrome in Carcinus aestuarii (Crustacea: Decapoda: Portunidae) in the Volturno River
}

\author{
Monique Mancuso ${ }^{1 *}$, Renata Zaccone ${ }^{1}$, Francesca Carella², Paola Maiolino ${ }^{3}$ and Gionata De Vico ${ }^{2}$ \\ ${ }^{1}$ Institute of Coastal Marine Environment, UOS of Messina (IAMC)-CNR Spianata S. Raineri, 86, 98122, Messina, Italy \\ ${ }^{2}$ Dept of Biological Sciences, University of Naples Federico II, via Mezzocannone 8, 80134, Naples, Italy
}

${ }^{3}$ Dept of Pathology and animal health, University of Naples Federico II, Via Federico Delpino, 1, 80137, Naples, Italy

\begin{abstract}
In this study is reported the first episode of a Shell Disease Syndrome (SDS) in wild specimens of Carcinus aestuarii from the polluted Volturno River estuary. Collected crabs showed erosive and ulcerative "black spot" lesions on the exoskeleton; histologically the lesions ranged from a mild to extensive and severe damages and intense haemocyte infiltration. Bacterial isolation confirmed the presence of some marine bacterial species with chitinolytic activity. The authors suggest that the detection of sds in wild crabs living in polluted waters could be used to monitor the health status of this environment.
\end{abstract}

Keywords: Shell disease syndrome; Histopathology; Bacteriology; Carcinus aestuarii; Biomonitor

\section{Introduction}

Shell Disease Syndrome (SDS) is a term that describes a broad range of lesions in the exoskeleton of crustaceans supported by different species of chitinolytic opportunistic bacteria, belonging to different genera: Vibrio, Listonella, Aeromonas, Pseudomonas, Alteromonas, Flavobacterium, Spirillum, Moraxella, Pasteurella and Photobacterium [1-3].

In stressed and/or wounded specimens these bacteria can cause erosions on the exoskeleton and septicemia; moreover systemic tissues damages can occur if the bacteria complex penetrates internally [2]. SDS affects various species of crustaceans all over the world 35 i.e.: Callinectes sapidus, Cancer magister, Cancer pagurus, Cancer irroratus, Cancer borealis [4-8].

The disease is common in aquaculture facilities or in polluted waters [9-13]. In the past years the prevalence of the disease in natural populations has increased and the lack of baseline data on its distribution in the Mediterranean area represents a limit toward a better understanding of this syndrome Sindermann [14].

The aim of the present paper is to describe, for the first time, the presence of SDS in a wild population of Carcinus aestuarii. C. aestuarii is a common crab, belonging to the Portunidae Family; it has an extensive distribution in estuarine and lagoon waters of the Mediterranean Sea and plays an important ecological role in lagoon ecosystems as a component of the diet of fish Stentiford [15].

The examined specimens were collected from the Volturno River estuary. This area is a heavily polluted area of the Campania region (Southern Italy). The inorganic and organic compounds are the major contaminants $[16,17]$. The presence of high levels of nitrate indicating a severe contamination related to human activities (application of nitrogen fertilizers and wastewater disposal) was also reported Amodio [18] in a pollution risk map of the Volturno River. Degraded environmental conditions are generally considered to be associated with shell disease in crabs [1]. Low water quality might suppress immune-defence of residing animals leading to a weakened physiological state [4].

\section{Materials and Methods}

In the spring of 2007, 50 adults C. aestuarii were collected from the
Volturno River estuary (Campania, Italy) with lobsterpots, in a single sampling, and submitted to our laboratory. All crabs showed "black spots" lesions typical of shell disease; each specimen was measured (carapace width) and the sex was determined. Lesions and disease signs (i.e.: limbs losses, lesions size, shape, color, distribution and position) 3 were 61 recorded and photographed.

Histological and microbiological assays were performed. For histological examination the diseased specimens were sacrificed and fixed with neutral buffered 10\% formalin. The exoskeleton (decalcified in $5 \%$ formic acid), and the internal organs were processed for routine histopathology: dehydrated in graded alcohols, embedded in paraffinwax, sectioned at 4-5 $\mu \mathrm{m}$ and stained with Haematoxylin-Eosin ( $\mathrm{H} \&$ E). Special staining as Periodic Acid Shiff (PAS) and Gram were also carried out.

Carapace lesions prevalence and severity was categorized following the Stages Disease Index [19]: in the $1^{\text {st }} 69$ stages the mild lesions consisted in small erosion of the epicuticle and calcified endocuticle; more extensive and profound erosion were characterized by endocuticle lesions with haemocytes infiltration and melanin deposition $\left(2^{\text {nd }}\right.$ and $3^{\text {rd }}$ stages). For microbiological assays, exoskeleton surface was sterilized with $70 \%$ ethanol and successively the hemolymph was withdrawn at joint of carapace and $5^{\text {th }}$ pereiopod into a sterile $1 \mathrm{ml}$ syringe. Moreover, the lesions were scraped with a $0.1 \mathrm{ml}$ disposable plastic loop. Hemolymph and scraped material were then spread on Marine Agar (Microbial Diagnostics) and TCBS agar (Thiosulfate Citrate Bile Sucrose-Oxoid). Cultures were incubated at $24 \pm 1{ }^{\circ} \mathrm{C}$ for $24-48$ hours. Suspected colonies were isolated in pure culture and the strains were identified by morphological and biochemical tests [10].

*Corresponding author: Monique Mancuso, Institute of Coastal Marine Environment, Section of Messina (IAMC)-CNR Spianata S. Raineri, 86, 98122, Messina, Italy; E-mail: monique.mancuso@iamc.cnr.it

Received June 24, 2013; Accepted July 25, 2013; Published July 29, 2013

Citation: Mancuso M, Zaccone R, Carella F, Maiolino P, Vico GD (2013) First Episode of Shell Disease Syndrome in Carcinus aestuarii (Crustacea: Decapoda: Portunidae) in the Volturno River. J Aquac Res Development 4: 191 doi:10.4172/2155-9546.1000191

Copyright: @ 2013 Mancuso M, et al. This is an open-access article distributed under the terms of the Creative Commons Attribution License, which permits unrestricted use, distribution, and reproduction in any medium, provided the original author and source are credited. 
Citation: Mancuso M, Zaccone R, Carella F, Maiolino P, Vico GD (2013) First Episode of Shell Disease Syndrome in Carcinus aestuarii (Crustacea: Decapoda: Portunidae) in the Volturno River. J Aquac Res Development 4: 191 doi:10.4172/2155-9546.1000191

\section{Results}

The specimens of C. aestuarii were all adults, the sex ratio was 0.20 (40 males and 10 females). The carapace width ranged from 18.84 to $37.70 \mathrm{~mm} .18 \%$ of the animals was in moulting state. All animals were diseased, $74 \%$ showed eroded or ulcerated lesions variable in shape (circular, oval, linear), in dimension (ranging from 1 to $7 \mathrm{~mm}$ ) and colour (pale, brown, black) the so-called black spot lesions (Figure 1). Lesions were single or multiple and some coalesced leading to largest ones. The majority (56\%) of the lesions occurred at the unsclerotized area of limbs, at the dactylus, at the 4propods, at the carpus, at leg tips and at the ventral 87 level, extending to the abdomen and sternum (Figure 2). Many animals showed necrotic areas at the point of the limb loss.

The males, that presented a greater size than females, displayed the highest number of outer lesions. Under microscopic observation, the lesions ranged from small erosion of the epicuticle and calcified endocuticle to more extensive and deeper endocuticle lesions with haemocytes infiltration and melanin presence (Figure 2). Mild lesions were characterized by endocuticular involvement at dactylus resulting in its complete loss with a moderate hyperplasia/hypertrophy of the epithelium. In other cases carapace ulcerations on the dorsal side was recorded measuring 5-6 $\mathrm{mm}$. Ulcers were represented by the total loss of epicuticle, exocuticle and outer calcified endocuticle with melanin deposition and prominent accumulations of haemocytes nodules. At times lesions also involved muscular cells accompanied by a severe interstitial haemocytes infiltration and degenerative changes. Melanin depositions with haemocytes aggregates and PAS positive fibrinous-like material (so called pseudo membrane) were observed in the central and deeper portion of the lesion. On carapace, the gram staining underlined the presence of Gram negative bacteria within the lesion (Figure 2). In mild and most advanced lesions necrotic gills and degenerative changes in the hepatopancreas were frequently accompanied by inflammatory process. Interestingly gill's nephrocytes the analogous of fixed macrophages of Vertebrates involved in the uptake of toxic and/ or foreign elements in the hemolymph were increased in number and size. The majority of cultured bacteria from the hemolymph and lesion pad were Gram negative. Identification showed that bacterial strains belonged to: Vibrio alginolyticus (12 strains), Listonella anguillarum (6),

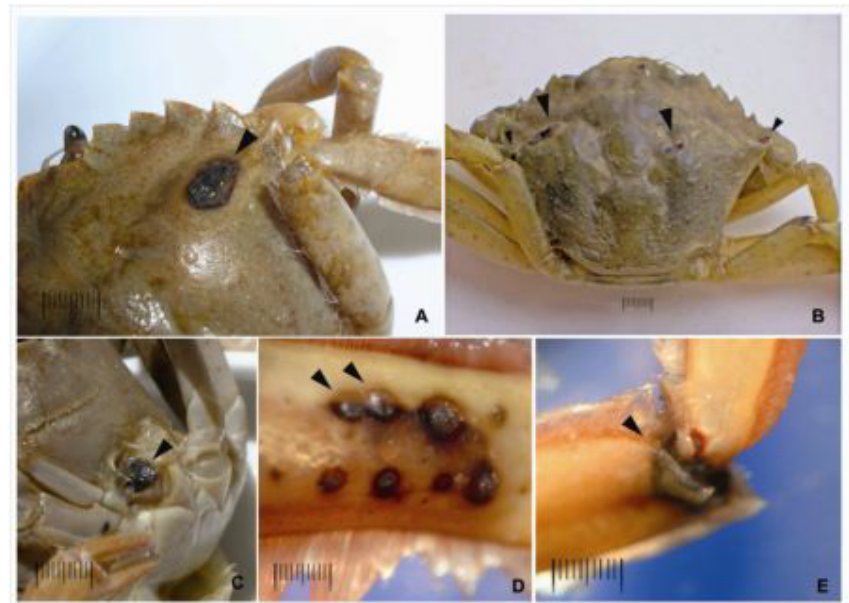

Figure 1: Carcinus eastuarii Shell disease macroscopical lesions. A-B: Dorsal lesions with $\operatorname{deep}(\mathrm{A})$ and moderate ulceration $(B)$. C. cheliped loss with melanin deposition D-E: Limb lesions at tip and joint level (bar=1 cm).

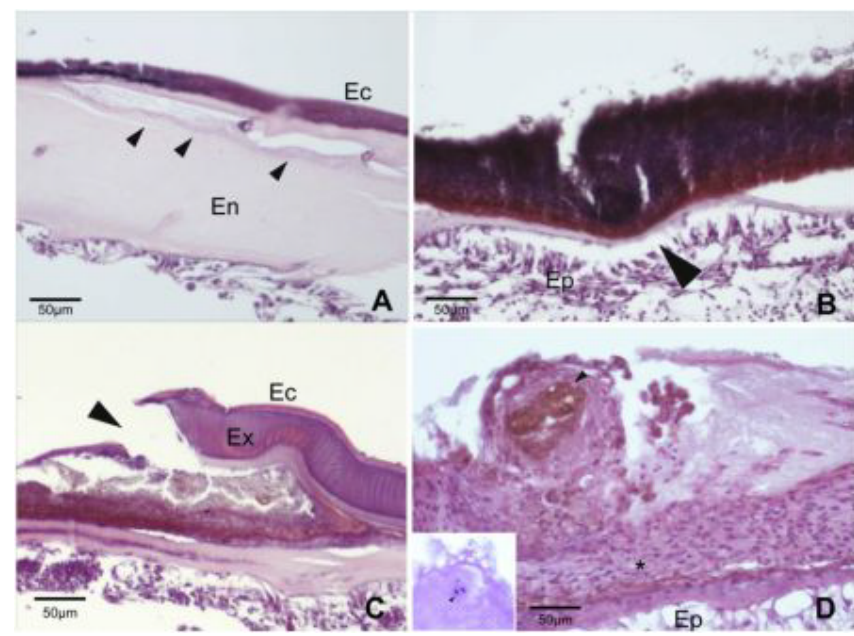

Figure 2: Carcinus eastuarii Shell disease histological observation. A-B: mild shell lesions: epicuticle and exocuticle lesion with early $(A)$ and advanced $(B)$ endocuticle involment (25X); C-D: dorsal ulcers: epicuticle and procuticle loss (C) showing hemocytes and nodule formation (arrowhead) (D) (30X). Insert: Gram staining shows Gram negative bacteria within the lesion (40X). Ec: epicuticle, Ex: exocuticle; En: endocuticle .Ep:epithelia $\left({ }^{*}\right)$ haemocytes.

Vibrio fluvialis (6), Vibrio sp (4) and Aeromonas hydrophila (4).

\section{Discussion}

In the $C$. aestuarii specimens the evolution of the disease seemed to follow the same pattern described by Martin et al. [20]. The males, greater in size than females, displayed a higher percentage 113 of deep lesions and limb loss, according to other authors [21] which reported a higher prevalence and infection intensity in males of Cancer pagurus.

The crabs with more severe disease displayed histopathological alterations of several organ and tissue systems, including systemic melanised haemocyte nodules, with a chitinolytic activity in the hemolymph as previously reported [22].

Moreover many of the specimens were in moult state and therefore more susceptible to bacterial attack [23]. The presence of Gram negative chitinolytic bacteria in the lesions and hemolymph of diseased animals showed that these bacteria are involved in the pathogenesis of the shell disease as opportunistic microorganisms $[24,25]$. The diseased animals were all adults; this observation is supported by previous studies [26] that noted the prevalence of the disease in populations of older crabs.

Involvement of internal organs has been reported during shell disease; gill necrosis and hepatopancreas degeneration are the most frequently recorded lesions [22-27]. The increased nephrocytes number and dimension in crustaceans, along with necrotic and degenerative changes in the gills and hepatopancreas, respectively, have been frequently observed as a consequence of polluted environment exposure [28]. In this context, it is well known that the Volturno River has been identified as a critical point for the pollution of adjacent marine waters, carrying pollutants from domestic, industrial and agricultural sources [16-17]. Furthermore, many anthropogenic factors are known to exacerbate the SDS: heavy metals could suppress the immune system [29-30], enhance chitinase activity [31] while some insecticides (methoprene) have also been found to inhibit chitin synthesis [32-33].

C. aestuarii is a more resistant to the pollution compared to the other species of Decapoda. Ricciardi et al. [34] demonstrated that 
Citation: Mancuso M, Zaccone R, Carella F, Maiolino P, Vico GD (2013) First Episode of Shell Disease Syndrome in Carcinus aestuarii (Crustacea: Decapoda: Portunidae) in the Volturno River. J Aquac Res Development 4: 191 doi:10.4172/2155-9546.1000191

C. aestuarii caught in the polluted Lagoon of Venice, can be used as biomarkers with respect to the organic pollutants. In conclusion, as supported by the work reported above, even in our 139 case the presence of SDS in a wild population of C. aestuarii, could be suggested as biomarker of the environmental stress in the Volturno River. To our knowledge this is the first description of the disease in the wild population of Carcinus aestuarii, which could be used as a useful tool to unravel the relationship between environmental stressful conditions and the occurrence of the disease.

\section{References}

1. Wang W (2011) Bacterial diseases of crabs: a review. J Invertebr Pathol 106 $18-26$.

2. Vogan CL, Costa-Ramos C, Rowley AF (2002) Shell disease syndrome in the edible crab, Cancer pagurus-isolation, characterization and pathogenicity of chitinolytic bacteria. Microbiology 148: 743-754.

3. Costa-Ramos C, Rowley AF (2004) Effects of extracellular products of Pseudoalteromonas atlantica on the edible crab, Cancer pagurus. Appl Environ Microbiol 70:729-735

4. Noga EJ, Engel DP, Arroll TW, McKenna S, Davidian M (1994) Low serum antibacterial activity with increased prevalence of shell disease in blue crabs, Callinectes sapidus. Dis Aquat Org 19: 121-128.

5. Morado JF, Sparks AK, O'Clair CE (1988) A preliminary study of idiopathic lesions in the Dungeness crab, Cancer magister, from Rowan Bay, Alaska. Mar Environ Res 26: 311-318.

6. Powell A, Rowley AF (2005) Unchanged prevalence of shell disease in the edible crab, Cancer pagurus, four years after decommissioning a sewage outfall at Langland Bay, U.K. Dis Aquat Organ 68: 83-87.

7. Sawyer TK (1991) Shell disease in the Atlantic rock crab, Cancer irroratus say, 1817, from the north eastern United States. J Shellfish Res 10: 495-497.

8. Bower SM, McGladdery SE, Price IM (1994) Synopsis of infectious diseases and parasites of commercially exploited shellfish. Ann Rev Fish Dis 4: 1-199.

9. Carella F, Marino F, Maiolino P, Grassi P, Danzè A, et al.(2010) Aspetti microbiologici e anatomo patologici della Shell Disease Syndrome in cinque differenti specie di crostacei decapodi. Ittiopatologia 7: 33-41.

10. Mancuso M, Costanzo MT, Maricchiolo G, Gristina M, Zaccone R, et al. (2010) Characterization of chitinolityc bacteria and histological aspects of Shell Disease Syndrome in European spiny lobsters (Palinurus elephas) (Fabricius 1787). J Invertebr Pathol 104: 242-244.

11. Mancuso M, Zaccone R, Genovese L, Maricchiolo G, Calabrò A, et al. (2006 a) Brown spot disease: un fattore limitante la riproduzione controllata di mazzancolla (Melicerthus kerathurus). Ittiopatologia 3: 15-20.

12. Mancuso M, Maricchiolo G, Zaccone $R$ (2006 b) Determinazione rapida di Vibrio sp. durante lo sviluppo larvale di Penaeus kerathurus (Forskall 1775) in microcosmo. Biologia Marina Mediterranea 13: 514-517.

13. Sindermann CJ (1989) The shell disease syndrome in marine crustaceans. NOAA Technical Memorandum MFS-F: NEC-64.

14. Stentiford GD (2008) Diseases of the European edible crab (Cancer pagurus): a review. ICES Journal of Marine Sciences 65: 1578-1592.

15. Mori M, Mancon R, Fanciulli G (1990) Notes of the reproductive biology of Carcinus aestuarii Nardo (Crustacea, Decapoda) from the lagoon of San Teodoro (Island of Sardinia, Italy). Rivista di Idrobiologia 29:763-774.

16. Melluso G, Esposito A, Guida M, Maurano F, Trieff NM, et al. (1994) Distribution of Inorganic and Organic Pollutants in River Sediments in Campania, Italy Bull Environ Contam Toxicol 52: 13-18.

17. Amodio-Cocchiari R, Arnese A (1988) Organochlorine pesticide residues in fish from Southern Italian rivers. Bull Environ Contam Toxicol 40: 233-239

18. Corniello A, Ducci D, Ruggieri G (2006) The pollution risk map of the southern part of the Volturno River plain (Southern Italy). Geophysical Research Abstracts 8: 03703 .

19. Estrella B (1991) Shell disease in American lobster (Homarus americanus, $H$ Milne Edwards, 1937) from Massachusetts coastal waters with considerations for standardizing sampling. J Shellfish Res 10: 483-488.

20. Martin GG, Quintero M, Quigley M, Khosrovian H (2000) Elimination of sequestered material from the gills of Decapod Crustacean. J Crustacean Bio 20: $209-217$

21. Vogan CL, Llewellyn PJ, Rowley AF (1999) Epidemiology and dynamics of shell disease in the edible crab Cancer pagurus: a preliminary study of Langland Bay, Swansea, UK. Dis Aquat Organ 35: 81-87.

22. Vogan CL, Costa-Ramos C, Rowley AF (2001) A histological study of shell disease syndrome in the edible crab Cancer pagurus. Dis Aquat Org 47: 209217.

23. Smolowitz RM, Bullis RA, Abt DA (1992) Pathological cuticular changes of winter impoundment shell disease preceding and during intermolt in the American lobster, Homarus americanus. Biol Bull Woods Hole 183: 99-112.

24. Musgrove R, Geddes M, Thomas C (2005) Causes of tail fan necrosis in Southern Rock Lobster, Jasus edwardsii. New Zealand. Journal Mar Freshw Res 39: 293-304.

25. Porter $L$ (2004) The microbiology and pathology of shell disease in the Florida Spiny Lobster, Palinurus argus with a comparison to shell disease in the American Lobster, Homarus americanus. PHD Thesis.

26. Ayres PA, Edwards E (1982) Notes on the distribution o f Black Spot' shell disease in crustacean fisheries. Chemistry and Ecology 1: 125-130.

27. Ryazanova TV (2005) Histopathological changes Associated with She Disease in the Red King Crab Paralithodes camtschaticus (Tilesius, 1815). Russian Journal of Marine Biology 31: 359-366.

28. Stentiford GD, Longshawa MP, Lyons B, Jonesa G, Greena M, et al. (2003) Histopathological biomarkers in estuarine fish species for the assessment of biological effects of contaminants. Mar Environ Res 55: 137-159.

29. Hernroth B, Baden SP, Holm K, Andre T, Söderhäll I (2004) Manganese induced immune suppression of the lobster, Nephrops norvegicus. Aquat Toxicol 70 223- 231.

30. Le Moullac G, Haffner P (2000) Environmental factors affecting immune responses in Crustacea. Aquaculture 191:121-131.

31. Vogan CL, Powell A, Rowley AF (2008) Shell Disease in crustaceans-just chitin recycling gone wrong? Environ Microbiol 10: 826-835.

32. Walker AN, Bush P, Puritz J, Wilson T, Chang ES, et al. (2005 a) Metabolic effects of acute exposure to methoprene in the American lobster, Homarus americanus. J Shellfish Res 24: 787-794.

33. Walker AN, Bush P, Puritz J, Wilson T, Chang ES, et al. (2005 b) Bioaccumulation and metabolic effects of the endocrine disruptor methoprene in the lobster Homarus americanus. Integr Comp Biol 45: 118-126.

34. Ricciardi F, Matozzo V, Binelli A, Marin MG (2010) Biomarker responses and contamination levels in crabs (Carcinus aestuarii) from the Lagoon of Venice: An integrated approach in biomonitoring estuarine environments. Water Research 4: 1725-1736. 